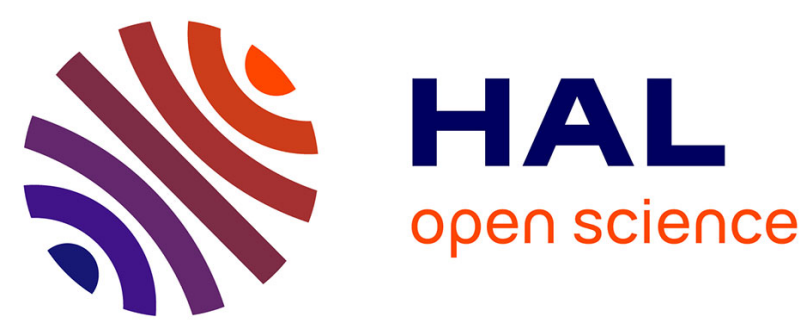

\title{
Potential allelopathic effect of Pinus halepensis in the secondary succession: an experimental approach
}

Catherine Fernandez, Benjamin Lelong, Bruno Vila, Jean-Philippe Mevy, Christine Robles, Stephane Greff, Sylvie Dupouyet, Anne Bousquet-Mélou

\section{- To cite this version:}

Catherine Fernandez, Benjamin Lelong, Bruno Vila, Jean-Philippe Mevy, Christine Robles, et al.. Potential allelopathic effect of Pinus halepensis in the secondary succession: an experimental approach. Chemoecology, 2006, 16 (2), pp.97 - 105. 10.1007/s00049-006-0334-z . hal-01764231

\section{HAL Id: hal-01764231 \\ https://hal-amu.archives-ouvertes.fr/hal-01764231}

Submitted on 11 Apr 2018

HAL is a multi-disciplinary open access archive for the deposit and dissemination of scientific research documents, whether they are published or not. The documents may come from teaching and research institutions in France or abroad, or from public or private research centers.
L'archive ouverte pluridisciplinaire HAL, est destinée au dépôt et à la diffusion de documents scientifiques de niveau recherche, publiés ou non, émanant des établissements d'enseignement et de recherche français ou étrangers, des laboratoires publics ou privés. 


\title{
Potential allelopathic effect of Pinus halepensis in the secondary succession: an experimental approach
}

\author{
Catherine Fernandez, Benjamin Lelong, Bruno Vila, Jean-Philippe Mévy, Christine Robles, Stéphane Greff, \\ Sylvie Dupouyet and Anne Bousquet-Mélou
}

Institut Méditerranéen d'Ecologie et Paléoécologie (IMEP) - UMR CNRS 6116, LBEM, Université de Provence, Centre de St. Jérôme, Case 421 , 13397 Marseille, Cedex 20, France

Summary. Recent economic and social changes in north Mediterranean regions have led to an important rural depopulation. Consequently, meadows developed on abandoned agricultural lands (characterized by high species richness) undergo reforestation. These former fields are mainly colonized by Pinus halepensis Miller, which is known to synthetize a wide range of secondary metabolites, among these, some could influence plant succession through allelopathy. The allelopathic potential of $P$. halepensis, was tested against two target species (Lactuca sativa L. and Linum strictum L.) with aqueous extracts obtained from different organs (root and needle) taking into account the individual age $( \pm 10, \pm 30$ and $>60$ years old). Root and needle extracts affected differently germination and growth of the two target species, the responses varying with concentration of extracts, age and organs tested. The strongest inhibitory effect was observed on the germination and growth of L. strictum, exposed to needle extracts of young P. halepensis $( \pm 10$ years old), and root extracts of older $P$. halepensis ( $>30$ years old). These extracts contained several phenolic acids (e.g. 4-hydroxybenzoic acid and p-coumaric acid), which are known as allelochemicals and their concentrations vary with age and organ tested. Hence, $P$. halepensis could influence secondary succession through the release of potential allelochemicals in the environment by leaf leachates or root exudates.

Key words. Allelopathy - phenolic compounds - land abandonment - plant succession - ecosystem functioning Mediterranean ecosystem

\section{Introduction}

The Mediterranean region has an intense and ancient agricultural history, but recent rural depopulation has greatly modified land occupation, in north Mediterranean countries, since the beginning of the $19^{\text {th }}$ century (Barbero et al., 1990; Lepart and Debussche, 1992; Preiss et al., 1997). These changes have led to a strong reforestation through secondary

Correspondence to: Anne Bousquet-Mélou, e-mail: anne.bousquet-melou @ up.univ-mrs.fr succession, where the abandoned soil is, at the beginning, free of vegetation other than crops or pastures (Gilmore, 1999). Although the different stages of successional dynamics leading to forest ecosystems are well described (Lepart and Escarré, 1983), the functional mechanisms involved are poorly documented or unknown. Moreover, some authors consider that replacement of plant species during succession is partly due to allelopathic mechanisms (Rice, 1984; Pellissier, 1993; Reigosa et al., 1999).

In Provence (South-East of France), Pinus halepensis Miller (Pinaceae, Pinales), which is a pioneer and expansionist species, colonizes abandoned agricultural land characterized by high biodiversity (Lepart and Debussche, 1992; Tatoni, 1992; Roche and Tatoni, 1995; Quézel, 2000). The result is an almost monospecific young forest which leads to paraclimaxes that delay the establishment of oak forest ecosystems (Quézel and Médail, 2004).

By its richness in secondary metabolites (Pasqua et al., 2002; Macchioni et al., 2003; Maestre et al., 2003; Pasqualini et al., 2003), P. halepensis could play an important role, in secondary succession through several processes. For example, secondary compounds (terpenoids and/or phenolic compounds) can affect root symbionts and site quality through interference with decomposition, mineralization and humification (Kuiters, 1990; Kainulainen and Holopainen, 2002). They could also influence secondary succession by interspecific competition through allelopathy (Rice, 1984; Lambers et al., 1998). Allelochemicals (mostly phenolic compounds and terpenoids; Rice, 1984; Rizvi et al., 1999) can be released by different ways: roots exudation, decomposition of plant organs (e.g. litter) or rain leaching (Rice, 1984). Concerning P. halepensis, Maestre et al. (2003), observed an inhibitory effect of this species on seedling establishment of various species in pine stands suggesting allelopathic effects of litter or root exudates. Moreover, allelopathic potential may be modified by several factors such as the age of the donor plant (Inderjit and Asakawa, 2001).

The aim of this study was to test (1) the allelopathic potential of $P$. halepensis, through its different organ-sources (needles for leaching and roots for exudation), and (2) its ageing at different stages of secondary succession. This would allow us to better understand the secondary succession that takes place in Mediterranean regions undergoing agricultural land abandonment. 
Table 1 Characteristics of study sites and trees of $P$. halepensis (Y: young pines; M: medium-aged pines; O: old pines; Mean age, diameter, height: \pm standard deviation and global index (Global indices between -19 and 59 correspond to high fertility for P. halepensis)

\begin{tabular}{|c|c|c|c|c|c|c|}
\hline Site id & Coordinates & Altitude (m) & $\begin{array}{l}\text { Mean age of } \\
\text { pines (years) }\end{array}$ & $\begin{array}{c}\text { Mean diameter } \\
\text { of pines }(\mathrm{cm})\end{array}$ & $\begin{array}{l}\text { Mean height } \\
\text { of pines (m) }\end{array}$ & $\begin{array}{c}\text { Global } \\
\text { index }\end{array}$ \\
\hline \multirow[t]{2}{*}{ Y1 } & $43^{\circ} 46^{\prime} 1{ }^{\prime \prime} \mathrm{N}$ & & & & & \\
\hline & $5^{\circ} 19^{\prime} 49^{\prime \prime} \mathrm{W}$ & 269 & $9 \pm 1$ & $19 \pm 2$ & $4 \pm 1$ & 26 \\
\hline \multirow[t]{2}{*}{ Y2 } & $43^{\circ} 46^{\prime} 14^{\prime \prime} \mathrm{N}$ & & & & & \\
\hline & $5^{\circ} 17^{\prime} 45^{\prime \prime} \mathrm{W}$ & 265 & $12 \pm 1$ & $15 \pm 1$ & $4 \pm 1$ & 30 \\
\hline \multirow[t]{2}{*}{ Y3 } & $43^{\circ} 45^{\prime} 32^{\prime \prime} \mathrm{N}$ & & & & & \\
\hline & $5^{\circ} 17^{\prime} 45^{\prime \prime} \mathrm{W}$ & 217 & $11 \pm 2$ & $19 \pm 2$ & $5 \pm 1$ & 17 \\
\hline \multirow[t]{2}{*}{ M1 } & $43^{\circ} 46^{\prime} 00^{\prime \prime} \mathrm{N}$ & & & & & \\
\hline & $5^{\circ} 19^{\prime} 51^{\prime \prime} \mathrm{W}$ & 272 & $32 \pm 2$ & $33 \pm 4$ & $9 \pm 1$ & 16 \\
\hline \multirow[t]{2}{*}{ M2 } & $43^{\circ} 45^{\prime} 24^{\prime \prime} \mathrm{N}$ & & & & & \\
\hline & $5^{\circ} 19^{\prime} 11^{\prime \prime} \mathrm{W}$ & 217 & $28 \pm 5$ & $34 \pm 1$ & $12 \pm 2$ & 22 \\
\hline \multirow[t]{2}{*}{ M3 } & $43^{\circ} 45^{\prime} 59^{\prime \prime} \mathrm{N}$ & & & & & \\
\hline & $5^{\circ} 19^{\prime} 44^{\prime \prime} \mathrm{W}$ & 269 & $34 \pm 2$ & $37 \pm 5$ & $11 \pm 2$ & 27 \\
\hline \multirow[t]{2}{*}{ O1 } & $43^{\circ} 45^{\prime} 50^{\prime \prime} \mathrm{N}$ & & & & & \\
\hline & $5^{\circ} 19^{\prime} 42^{\prime \prime} \mathrm{W}$ & 248 & $78 \pm 3$ & $58 \pm 5$ & $15 \pm 2$ & 25 \\
\hline \multirow[t]{2}{*}{$\mathbf{O 2}$} & $43^{\circ} 46^{\prime} 18^{\prime \prime} \mathrm{N}$ & & & & & \\
\hline & $5^{\circ} 24^{\prime} 1{ }^{\prime \prime} \mathrm{W}$ & 350 & $68 \pm 3$ & $66 \pm 7$ & $16 \pm 2$ & 42 \\
\hline \multirow[t]{2}{*}{$\mathbf{O 3}$} & $43^{\circ} 45^{\prime} 0^{\prime \prime} \mathrm{N}$ & & & & & \\
\hline & $5^{\circ} 19^{\prime} 40^{\prime \prime} \mathrm{W}$ & 269 & $73 \pm 6$ & $57 \pm 8$ & $13 \pm 2$ & 29 \\
\hline
\end{tabular}

\section{Material and methods}

\section{Sampling sites}

In order to evaluate the variability of $P$. halepensis allelopathic potential in relation to different stages of secondary succession, three classes of age, of $P$. halepensis were chosen:

- meadows colonized by dispersed individuals of young $P$. halepensis ( \pm 10 years old) and named successional stage "Y".

- a monospecific forest stand of medium-aged P. halepensis $( \pm 30$ years old), recently closed and without understory and named successional stage "M".

- a "mature forest" of old $P$. halepensis (>60 years old) with welldeveloped understory and named successional stage "O".

Three replicates were selected for each successional stage (Table I).

Sites were selected along the southern hillside of the Luberon Mountains in the Natural Regional Park (South of France), on the basis of similar global index (climatic and topo-edaphic conditions) using a model developed by CEMAGREF (Ripert and Vennetier, 2002). All sites were characterized by deep agricultural soils $(>1 \mathrm{~m})$ of rendosol type according to the "référentiel pédologique" (AFES, 1995), Rendzic Leptosol according to FAO (FAO, 1998) and Rendoll in "Soil Taxonomy" (Soil Survey Staff, 1999), with no slope and a high fertility for P. halepensis (Table I).

\section{Material collection}

Needles and roots were collected from five individuals at each site. Needles were harvested from the entire tree crown and roots were sampled in close proximity to the pines (diameter $<1.5 \mathrm{~m}$ ). The samples were stored at $-24^{\circ} \mathrm{C}$.

\section{Bioassays}

Four principal pathways are known for allelochemicals to be released into the environment: litter decomposition, root exudates, vaporisation into the air, rain and dew transfering leaf compounds to the soil (Rice, 1984). Because some authors have shown that watersoluble compounds are probably most involved in allelophathy
(Vyvyan, 2002), natural leachates and root exudates were chosen to be approached in this study.

Needle and root extracts were prepared by soaking $50 \mathrm{~g}$ (fresh weight) in $250 \mathrm{ml}$ of distilled water (10\% dry weight as plant material contains $50 \%$ moisture). Extracts were prepared at room temperature and left in darkness for 24 hours. Diluted solutions (5 and $2.5 \%$ ) were prepared from the mother solution.

Two target species were selected: (1) Lactuca sativa L. var. batavia (Asteraceae, Asterales), species known for its sensitivity to allelopathic substances and frequently used for bioassays (Molina et al., 1991; Chiapusio et al., 1997; Chou et al.,1998), and (2) Linum strictum L. (Linaceae, Linales), present in open environments in Provence calcareous areas (Loisel, 1976), particularly in the first secondary succession stages following abandoned agricultural lands (Tatoni, 1992).

The use of L. sativa could demonstrate the possible mechanisms by which $P$. halepensis competes with other species while the results concerning $L$. strictum, which grows in the study area, have more ecological significance (Bousquet-Mélou et al., 2005).

Trials were carried out using glass Petri dishes with Whatman ${ }^{\circledR} \mathrm{n}^{\circ} 4$ filter papers (Molina et al., 1991; Bong-Seop, 1992; Chiapusio et al., 1997; Chou et al., 1998). Twenty seeds of each target species were placed in Petri dishes, to which $1 \mathrm{ml}$ of extract solution was added. The dishes were then regularly sprayed with an equal volume of the same extract solution until the end of the experiment. Three factors were tested: age (sampling site corresponding to the age of the stand), plant organ (needle or root), and dose (extract concentration). For controls, distilled water was used. Five replicates were used for each combination (age/ organ/ dose). Trials were carried out, during natural photoperiod, at a fixed temperature $\left(20.5{ }^{\circ} \mathrm{C} \pm 1{ }^{\circ} \mathrm{C}\right)$, and at $100 \%$ relative humidity, approximately. Two variables were analysed for the two target species: germination of seeds (rate and response curve), and length of seedlings (radicle, hypocotyl, and total) 5 days after germination.

\section{Osmotic pressure measurements}

To be sure that the inhibitor effects observed on germination rate and growth are not due to osmotic pressures but to allelochemicals of $P$. halepensis (Anderson and Loucks, 1966), osmolality $\left(\mathrm{mOsmol} / \mathrm{kg} \mathrm{H}_{2} \mathrm{O}\right)$ of all extracts $(10 \%)$ was measured with a micro-osmometer from Roebling (Type13/13DR - Autocal). 
Apparatus was recalibrated every 10 samples with deionized water and certified solution of $300 \mathrm{mOsmol} / \mathrm{kg} \mathrm{H}_{2} \mathrm{O}$ (even if no calibration drift was observed).

\section{Chemical analyses}

Instrumentation. Analyses were performed using a HewlettPackard GC6890 (coupled to a HP 5973N Mass Selective Detector) equipped with a HP5MS capillary column $(30 \mathrm{~m} \times$ $0.25 \mathrm{~mm} \times 0.25 \mu \mathrm{m}-\mathrm{J} \& \mathrm{~W}$ Scientific). Sample volumes were injected in a splitless mode for $1 \mathrm{~min}$ with an ALS 7683 Automatic Injector. Purge flow was set to $30 \mathrm{ml} / \mathrm{min}$ for qualitative study $(50 \mathrm{ml} / \mathrm{min}$ for quantitative one). Helium $(99.995 \%)$ was used as carrier gas. A constant flow of $1 \mathrm{ml} / \mathrm{min}$ was set throughout the run for both qualitative and quantitative analyses. For qualitative study, oven temperature was initially programmed at $70{ }^{\circ} \mathrm{C}$, ramped to $270{ }^{\circ} \mathrm{C}$ at a rate of $5{ }^{\circ} \mathrm{C} / \mathrm{min}$, where it remained for $10 \mathrm{~min}$. A second program for quantitative analyses was developed: oven temperature initially set at $50{ }^{\circ} \mathrm{C}$ was increased to $220{ }^{\circ} \mathrm{C}$ at a rate of $5 \% \mathrm{~min}$ where it remained for $6 \mathrm{~min}$. Injector temperature and MSD transfer line heater was held to 250 and $280^{\circ} \mathrm{C}$, respectively. The mass spectrometer parameters for EI mode were: ion source, $230{ }^{\circ} \mathrm{C}$; MS quadrupole, $150{ }^{\circ} \mathrm{C}$; electron energy, $70 \mathrm{eV}$; Electron Multiplier Energy, 1100-1200V; data were acquired in scan mode from 40 to 500amu for qualitative analyses and in "Selected Ion Monitoring" mode for quantitative analyses.

\section{Chemical supplies and quality}

Methylene chloride, ethyl acetate and acetonitrile HPLC grade were obtained from SDS (Peypin, France). Water of HPLC quality for plant extraction and chemical procedure was obtained from a Milli Q system (Millipore St-Quentin, France). Derivatization reagent, N,O-bis(trimethylsilyl)trifluoroacetamide (BSTFA) containing $1 \%$ trimethylchlorosilane (TMCS) for qualitative study was purchased from Fluka (Sigma-Aldrich). Methylation reagent (methyle iodure, $99.5 \%$ purity), internal standard (3-chloroanisole, $>97 \%$ purity), methanol HPLC grade, phenolics and aliphatic acids, phase transfer catalysts (tetrahexylammonium bromure THAB, $<99 \%$ purity, and tri-n-butylmethylphosphonium polymer bound - 1,4mmol Cl$/ g$ resin - TBMP) used for quantitative analysis were obtained from Sigma-Aldrich. Sodium chlorure and potassium dihydrogenophosphate of analytical grade were provided by Prolabo (VWR, France).

\section{Qualitative analyses}

Qualitative studies of chemical components were carried out on root and needle extracts of $P$. halepensis. For each analysis, three randomly-chosen extracts at $10 \%$ (used in bioassays) were mixed to be analysed.

The solutions were extracted three times with $25 \mathrm{ml}$ ethyl acetate. The three fractions were gathered and concentrated to dryness with rotary evaporator. The residue was suspended in $1 \mathrm{ml}$ of methylene chloride, and transferred to a $5 \mathrm{ml}$ vial. The procedure was repeated twice and the solution was evaporated to dryness under a stream of helium to remove residual water

A volume of $200 \mu$ of acetonitrile and $200 \mu \mathrm{l}$ of BSTFA+1\%TMCS was added to residue to produce trimethylsilyl derivatives. The solution was incubated at $70{ }^{\circ} \mathrm{C}$ for 1 hour, let to cool, filtrated and subjected to GC-MS.

\section{Quantitative analyses}

Quantitative analyses were performed on extracts of needles and roots of young and old pines. Analysis protocol for this quantitative study was adapted from Fiamegos et al. (2004) who developed an extraction-derivatization technique of phenolics via Phase Transfer Catalysis (PTC). The methodology was improved to fit phenolics and aliphatic acids (or diacids) methylation and extraction. The method was tested for 2 or 3 compounds of each chemical family: aliphatic acids (palmitic and stearic acids), aliphatic diacids (succinic and azelaic acids), simple phenols (catechol and pyrogallol), acetophenones (acetovanillone and acetosyringone), phenolic acids (4-hydroxybenzoic, protocatechuic and gallic acid) and cinnamic acids (p-coumaric, caffeic and sinapic acids). Chemical compounds were chosen on the basis of their occurrence in $P$. halepensis (qualitative analysis) or chemical interest to follow their capability to be methylated under these conditions before compound screening enlargment. Because of the methylation technique, the quantified derivatives may include several allelochemicals.

Stock solutions of compounds were prepared at $1 \mathrm{mg} / \mathrm{ml}$ dissolving $25 \mathrm{mg}$ pure standard in $25 \mathrm{ml}$ deionized water (or 50:50 (V/V) methanol/water for less soluble compounds). Adequate dilutions of stock solutions were made to carry out calibration curves. A buffer solution $1 \mathrm{M} \mathrm{KH}_{2} \mathrm{PO}_{4}$ was prepared by dissolving $13.60 \mathrm{~g}$ of salt in $100 \mathrm{ml}$ deionized water and adjusted to $\mathrm{pH} 8.0$ with diluted $\mathrm{NaOH}$. THAB $0,1 \mathrm{M}$ in dichloromethane $(217.3 \mathrm{mg}$ in $5 \mathrm{ml}$ ) and internal standard at $100 \mu \mathrm{g} / \mathrm{ml}$ in dichloromethane were also prepared.

The procedure occured in 35ml-Pyrex ${ }^{\circledR}$ tubes (Bibby Sterilin Ltd) equipped with PTFE screw caps: to $10 \mathrm{ml}$ extract solution was added a stirring bar, $500 \mu \mathrm{l}$ buffer solution $\mathrm{pH} 8.0,50 \mathrm{mg}$ TBMP, $100 \mu \mathrm{l}$ THAB $0.1 \mathrm{M}, 50 \mu \mathrm{l}$ internal standard, $850 \mu \mathrm{l}$ dichloromethane and $100 \mu \mathrm{l}$ methyle iodure. Tubes were hermetically sealed, and heated at $80^{\circ} \mathrm{C}$ during 1 hour to permit the methylation of compounds. After cooling, solutions were saturated with $\mathrm{NaCl}$ and shaked vigorously. After phase separation, organic layer was sampled, filtered onto $0.45 \mu \mathrm{m}$ filter syringe, and analysed by GC-MS.

The same procedure was applied to mixtures of adequate standard solutions to construct calibration curves. Methylated compounds were quantified relative to internal standard.

\section{Statistical analyses}

Differences in germination rate were carried out using a chi-square test (Scherrer, 1984). Differences in size (radicle, hypocotyl, total) according to age, dose or plant organ were tested using one-way or two-way ANOVA. Osmotic pressure of our extracts were compared with a threshold value $(0.5 \mathrm{~atm})$ with a mean comparison with theoretical mean test. Pearson correlation was performed between osmotic pressure and germination rate. Previously, normality and homoscedasticity were tested by Shapiro-Wilks' and Bartlett's tests, respectively. Statgraphics ${ }^{\circledR}$ (version 2.1) was used as software for all statistical analyses.

\section{Results}

\section{Bioassays}

L. sativa - The overall mean germination rate was $99 \%$, and there was no significant effect of factors on this parameter $\left(0.68<\chi^{2}<3.18 ; 0.365<\mathrm{p}<0.879\right)$. The seed germination of this species was not depressed.

Concerning needle extracts, mean length of radicles was significantly longer for all treatments compared to control (one-way Anova, $13.06<\mathrm{F}<171.30, \mathrm{p}<0.05$; Fig. 1). This stimulating effect was even greater with increasing age of pines, and more generally, with increasing dose of extracts (Tukey test; Fig. 1). Moreover, needle extract had no or little effect on hypocotyls growth (Tukey test; Fig. 1).

Concerning root extracts, older pines ( $>30$ years) inhibited growth and caused necroses of radicles at the extract concentrations of 5 and 10\% (one-way ANOvA, $12.40<\mathrm{F}<91.67$; $\mathrm{p}<0.05$; Fig. 1). For the lowest extract concentration, a significant stimulation of root growth was observed (Tukey test; Fig. 1). Similarly, root extracts stimulated generally the 

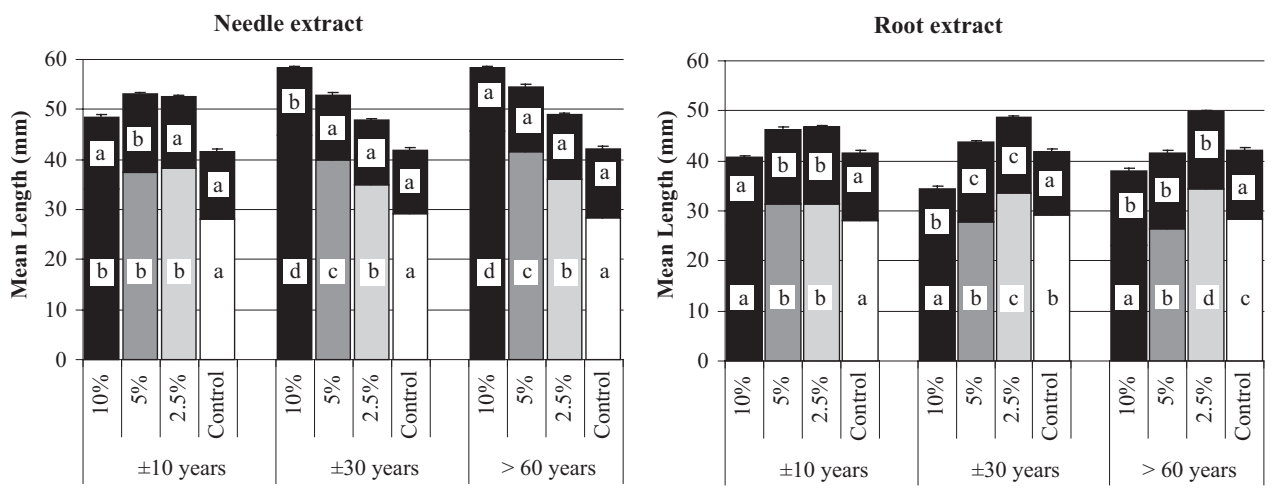

Fig. 1 Mean length of radicles and hypocotyls (and confidence interval at $95 \%$ ) of L. sativa as a function of $P$. halepensis age, organ nature (root or needle), and extract dose. Tukey's tests with regard to differences between doses are also presented for each organ (radicles in normal style and hypocotyls in italics). Values not different at $\alpha=5 \%$ are denoted with the same letter

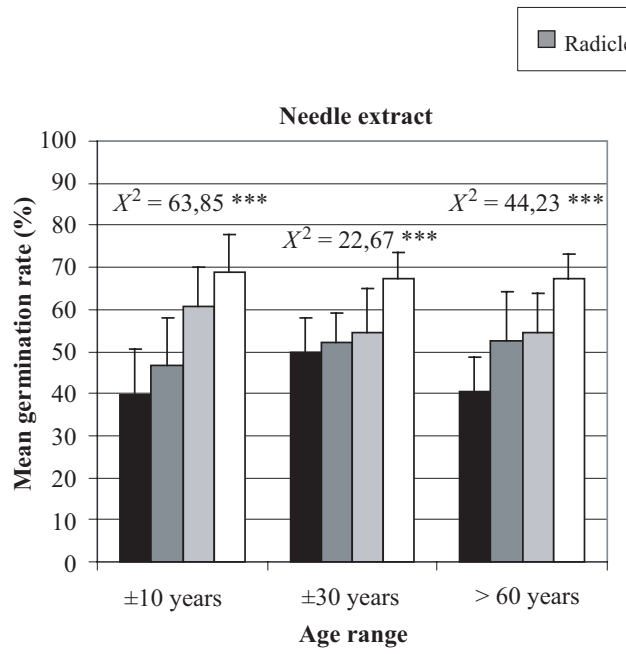

[ypocotyl

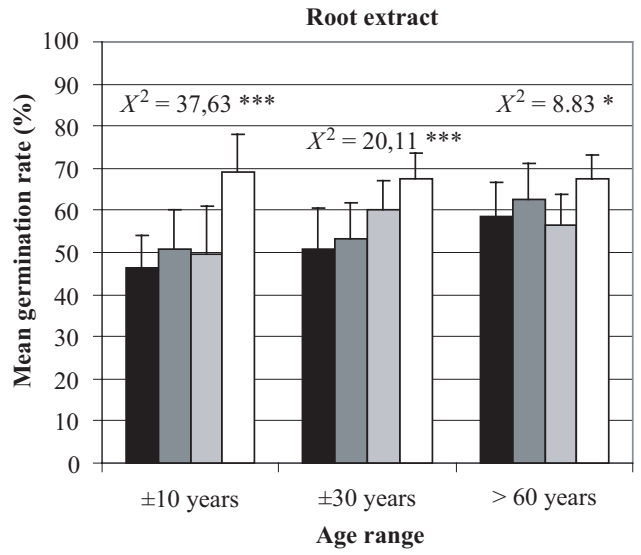

Fig. 2 Mean germination rate of L. strictum (and confidence interval at $95 \%$ ) as a function of $P$. halepensis age, organ nature (root or needle), and extract dose. Chisquare tests on germination rate are also given (chi-square value and $\mathrm{p}: *$ significant at $0.05 ; * *$ significant at 0.01 ; $* * *$ : significant at 0.001)

$10 \% \square 5 \% \square 2.5 \% \square$ Control

growth of hypocotyls (one way AnOvA, 4.22 < F < 78.56; $\mathrm{p}<0.05$; Fig. 1).

L. strictum - Root and needle extracts had significant effect on the germination of this species (chi-square test, $\mathrm{p}<0.05$; Fig. 2).

Germination was depressed but not totally suppressed. Indeed, mean germination rate varied between $40-60 \%$ with $P$. halepensis extracts. Control had the highest mean germination rate $(67-69 \%)$ all along the experiment (Fig. 3 ). Delayed germination that was later with increasing dose of extracts, was observed in particular for needle extracts of young pines.

Needle extracts had a significant, but not uniform, effect on growth of L. strictum seedlings (one-way ANOvA, $14.12<\mathrm{F}<205.95$; $\mathrm{p}<0.05$; Fig. 4). An important inhibitory effect, on both radicles and hypocotyls growth, was observed with needle extracts of young pines for the highest concentration. With most of combinations, an intermediate effect was observed: the needles extracts induced an inhibitory effect on radicle growth, but concomitant with a stimulative effect on hypocotyl growth (Tukey's tests; Fig. 4). Finally, a stimulatory effect was observed only for the older pines ( $>30$ years) at the lowest concentration.

Roots extracts had a significant, but not uniform, effect on growth of L. strictum seedlings (one-way ANOvA, $9.18<\mathrm{F}<69.76$; $\mathrm{p}<0.05$; Fig. 4). Generally, root extracts exhibited an inhibitory effect on radicle growth concomitant with a stimulative effect on hypocotyl growth except for the lower concentrations of the young pines extracts $(2.5-5 \%$; Tukey's tests; Fig. 4). Necroses of radicles were also observed with root extracts of older pines ( $>30$ years).

Osmotic pressure measurements. The mean osmotic pressure of aqueous extracts (10\%) varies from 0.35 to 0.69atm (Fig. 5). In our study, only the extract from roots of young pines $(10 \%)$ have an osmotic pressure significantly higher than $0.5 \mathrm{~atm}$ (mean comparison with theoretical mean) (Anderson and Loucks, 1966). Therefore, we show that there is no significant correlation $\left(R^{2}=0.0863\right.$, $\mathrm{p}>0.05)$ between osmotic pressure and germination rate (Fig. 6).

Chemical analyses. Qualitative analyses of chemical components confirmed the presence of numerous phenolic compounds such as benzeneacetic, 4-hydroxybenzoic, vanillic, veratric, syringic and $\mathrm{p}$-coumaric acids in $P$. halepensis organs (Appendix 1). Other non-phenolic acids such as lactic, succinic, palmitic acids were also observed.

The composition, with regard to several major compounds, differed between root and needle extracts (e.g. succinic and benzeneacetic acid; Appendix 1).

Quantitative analyses present significant differences between the various extracts analysed (Fig. 7): acetosyringone, 4-hydroxybenzoic acid, and acetovanillone are significantly higher in extracts of young pines needles and 

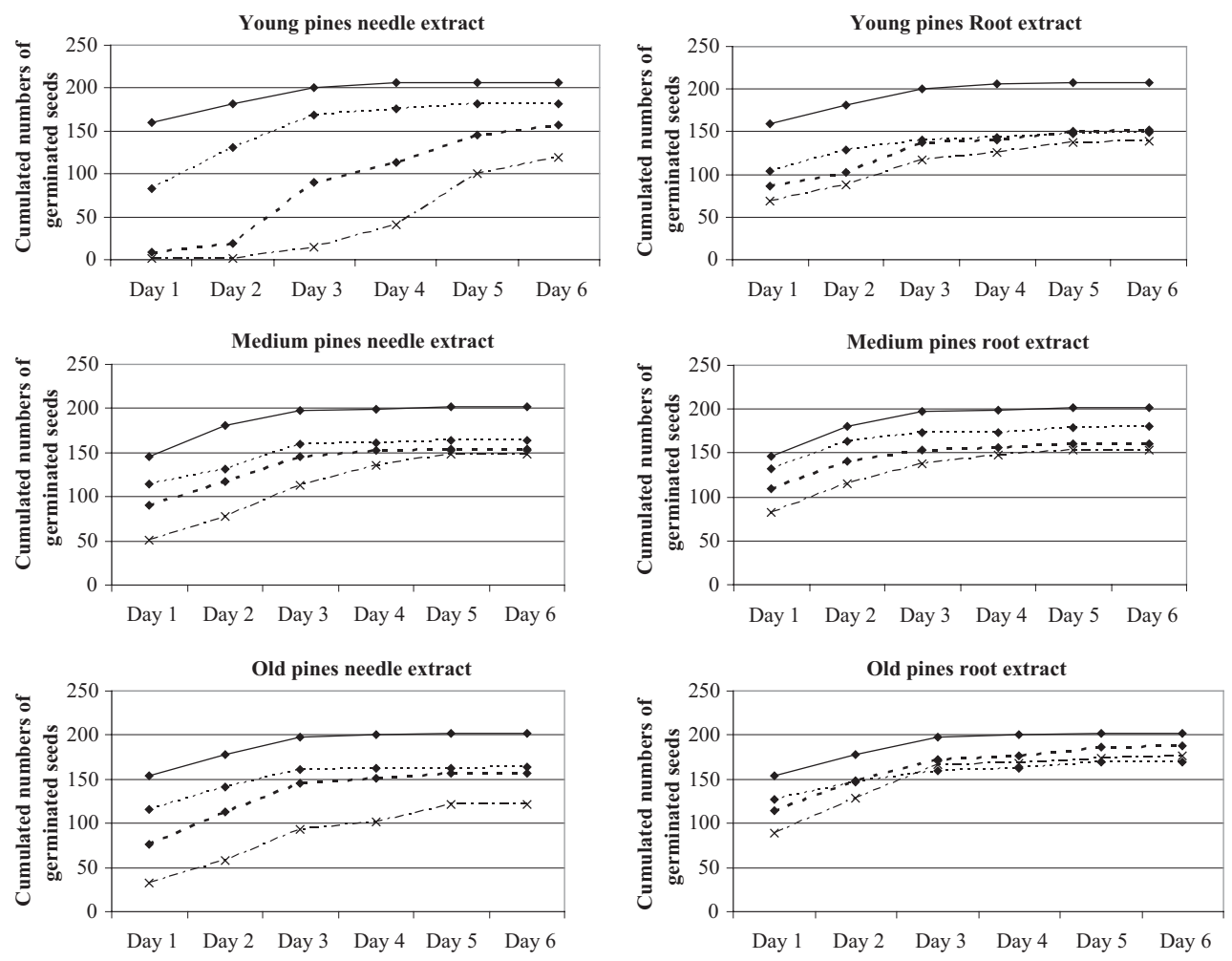

$$
\begin{array}{llllll}
\hline-* \cdot-10 \% & -\cdots & -5 \% & \cdots \cdot \cdots 2.50 \% & \longrightarrow \text { Control } \\
\hline
\end{array}
$$
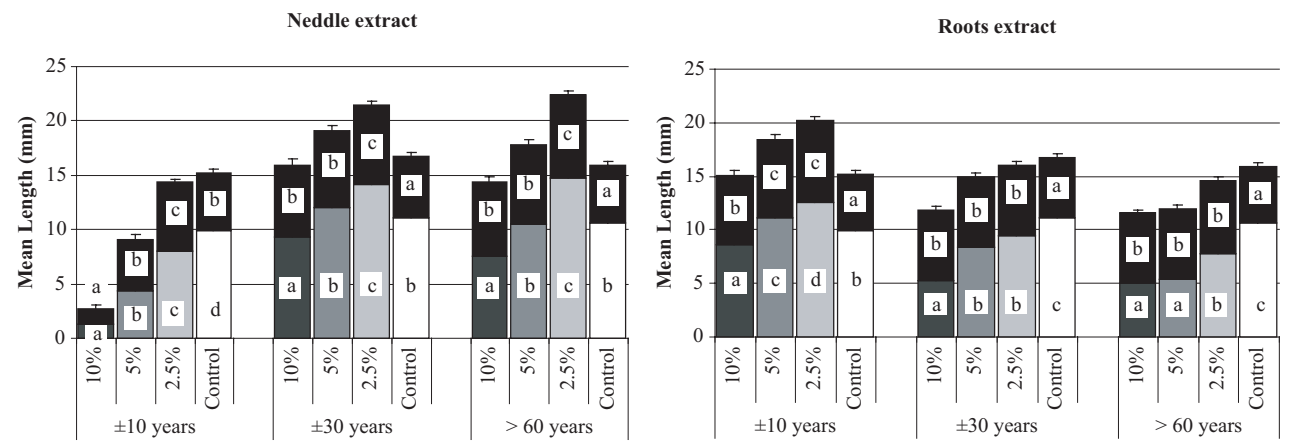

Fig. 4 Mean length of radicle and hypocotyl (and confidence interval at $95 \%$ ) of L. strictum as a function of $P$. halepensis age, organ nature (root or needle), and extract dose. Tukey's tests with regard to dose effects are also presented for each organ (radicles in normal style and hypocotyls in italics). Value not different at $\alpha=$ $5 \%$ are denoted with the same letter sinapic acid is significantly higher in extracts of young pines needles and old pines roots (one-way ANOvA, $3.88<\mathrm{F}<41.95$; $\mathrm{p}<0.05$; Tukey tests, $\mathrm{p}<0.05$ ).

\section{Discussion}

Allelopathic potential of $P$. halepensis

P. halepensis extracts affected differently germination and growth of the two target species according to the combination of the three parameters tested (dose of extracts, plant organs and age of trees). Similar effects on germination and growth due to Medicago arborea L. (Fabaceae, Fabales) have already been observed on $L$. strictum and $L$. sativa (Bousquet-Mélou et al., 2005). The germination rate of $L$. sativa is not affected by allelochemicals of $P$. halepensis while the germination of this species was depressed in other studies (Molina et al., 1991; Chiapusio et al., 1997; Chou et al.,1998).

According to Anderson and Loucks (1966), extracts used in this study have an osmotic pressure no greater than $0.5 \mathrm{~atm}$ (except for young roots extracts). So, effects observed on germination and growth can be due to allelochemicals of $P$. halepensis.

Our results showed three types of responses for the target species. The first effect observed is a total inhibition of both radicle and hypocotyl growth. This effect is 


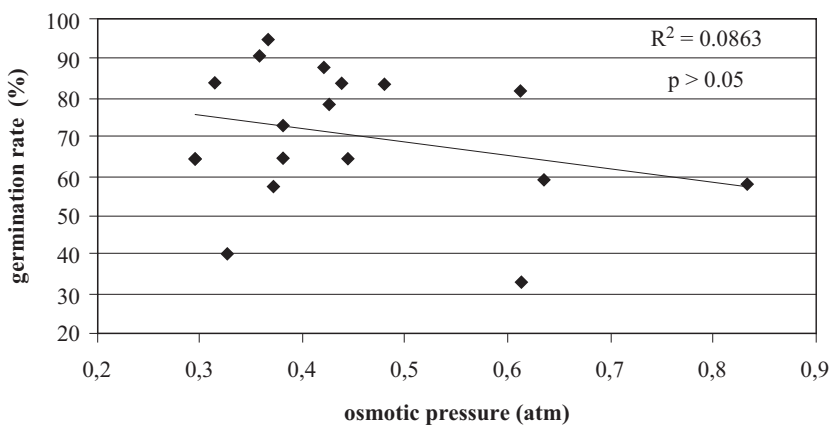

Fig. 6. Relation between osmotic pressure and relative germination rate (germination rate/control germination rate)
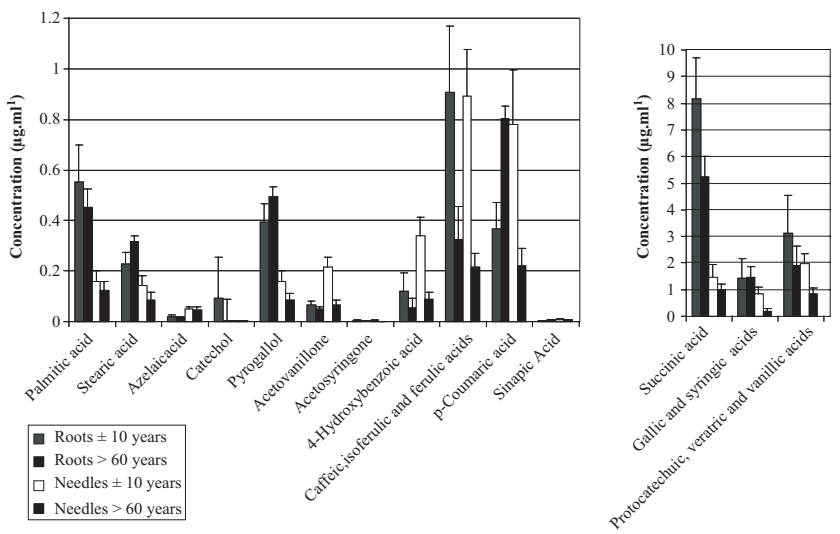

Fig. 7 Quantitative comparison of the allelochemicals studied between needles and roots extracts (10\% dry weight) for young and old pines

impairment may compromise the long-term survival of the seedlings. Indeed, as previously reported, the success of the reestablishment of some Mediterranean species greatly depends on the well-structured root systems of seedlings for an efficient resource capture (Green, 2005).

The last type of response is a simultaneous stimulatory effect on radicles and hypocotyls growth generally observed with the lower concentrations used. This response is a well known allelopathic property. Indeed, low concentration of allelochemicals can have a stimulating effect on target species growth (Rice, 1984). The stimulation of radicle growth is particularly observed for L. sativa seedlings. This may be due to a lesser sensitivity of this species compared to L. strictum as observed in other studies (Reigosa et al., 1996; Hong et al., 2004; Nektarios et al., 2005).

Consequences of potential allelopathy

of $P$. halepensis on the secondary succession

In our study, the germination of only L. strictum was affected by compounds present in the tested tissues, in particular those in needle extracts of young pines. This result is particularly interesting as $L$. strictum is found in the wild in the early successional stages following agricultural auxin transport were suspected to be involved in this redistribution of mitotic signals. However, in both cases, molecular alteration or specific physiological response, root architecture 
Appendix 1 Chemical compounds found in root and needle extracts of P. halepensis. RT: retention time (minutes) of compounds in the column. CAS: Identification number of Chemical Abstract Society

\begin{tabular}{|c|c|c|c|}
\hline RT & COMMON NAME & SCIENTIFIC NAME & CAS \\
\hline & Aliphatic acids & & \\
\hline 6.43 & Lactic acid & Propanoic acid, 2-hydroxy- & $50-21-5$ \\
\hline 6.50 & Malonic acid, diethyl ester & Propanedioic acid, diethyl ester & $105-53-3$ \\
\hline 7.93 & Levulinic acid & Pentanoic acid, 4-oxo- & \\
\hline 10.45 & Butyric acid, 4-hydroxy- & Butanoic acid, 4-hydroxy- & $591-81-1$ \\
\hline 12.45 & Succinic acid & Butanedioic acid & $110-15-6$ \\
\hline 15.71 & Non identified $(\mathrm{m} / \mathrm{z}=314)$ & & \\
\hline 28.36 & Palmitic acid & Hexadecanoic acid & $57-10-3$ \\
\hline \multirow[t]{2}{*}{31.87} & Stearic acid & Octadecanoic acid & $57-11-4$ \\
\hline & Terpenes & & \\
\hline 9.79 & Verbenone & $\begin{array}{l}\text { Bicyclo[3.1.1]hept-3-en-2-one, 4,6,6- } \\
\text { trimethyl- }\end{array}$ & $80-57-9$ \\
\hline 10.16 & Borneol & $\begin{array}{l}\text { Bicyclo[2.2.1]heptan-2-ol, 1,7,7- } \\
\text { trimethyl-,endo- }\end{array}$ & $507-70-0$ \\
\hline \multirow[t]{2}{*}{14.74} & Myrtenoic acid & $\begin{array}{l}\text { Bicyclo[3.1.1]hept-2-ene-2-carboxylic } \\
\text { acid, 6,6-trimethyl- }\end{array}$ & $19250-17-0$ \\
\hline & Phenolic acids & & \\
\hline 10.62 & Benzoic acid & Benzoic acid & $65-85-0$ \\
\hline 11.91 & Benzeneacetic acid & Benzeneacetic acid & $103-82-2$ \\
\hline 19.90 & 4-Hydroxybenzoic acid & Benzoic acid, 4-hydroxy- & $99-96-7$ \\
\hline 20.14 & 4-hydroxybenzeneacetic acid & Benzeneacetic acid, 4-hydroxy- & $156-38-7$ \\
\hline 22.95 & Vanillic acid & Benzoic acid, 4-hydroxy-3-methoxy- & $121-34-6$ \\
\hline 23.28 & Protocatechuic acid & Benzoic acid, 3,4-dihydroxy & $99-50-3$ \\
\hline 24.20 & Veratric acid & Benzoic acid, 3,4-dimethoxy- & $93-07-2$ \\
\hline 25.75 & Syringic acid & Benzoic acid, 4-hydroxy-3,5-dimethoxy- & $530-57-4$ \\
\hline \multirow[t]{2}{*}{27.10} & Gallic acid & Benzoic acid, 3,4,5-trihydroxy- & $149-91-7$ \\
\hline & Cinnamic acids & & \\
\hline 17.91 & Cinnamic acid & 2-Propenoic acid, 3-phenyl- & $140-10-3$ \\
\hline 26.15 & Ferulic acid & $\begin{array}{l}\text { 2-Propenoic acid, 3-(4-hydroxy-3- } \\
\text { methoxyphenyl)- }\end{array}$ & $537-98-4$ \\
\hline 26.42 & p-coumaric acid & 2-Propenoic acid, 3-(4-hydroxyphenyl)- & $501-98-4$ \\
\hline 26.51 & $\begin{array}{l}\text { Hydrocinnamic acid, } \mathrm{p}- \\
\text { hydroxy- }(\alpha \text { or } \beta) \text {-methyl }\end{array}$ & $\begin{array}{l}\text { Benzenepropanoic acid, 4-hydroxy- } \\
\text { ( } \alpha \text { or } \beta \text { )-methyl- }\end{array}$ & $\begin{array}{c}35456-48-5 \\
6739-21-5\end{array}$ \\
\hline 29.34 & Isoferulic acid & $\begin{array}{l}\text { 2-Propenoic acid, 3-(3-hydroxy-4- } \\
\text { methoxyphenyl)- }\end{array}$ & $25522-33-2$ \\
\hline 30.23 & Caffeic acid & $\begin{array}{l}\text { 2-Propenoic acid, 3-(3,4- } \\
\text { dihydroxyphenyl)- }\end{array}$ & $501-16-6$ \\
\hline 10.13 & $\begin{array}{l}\text { Alcohols } \\
\text { Phenylethyl alcohol }\end{array}$ & Benzeneethanol & $60-12-8$ \\
\hline 18.60 & $\begin{array}{l}\text { Phenolic alcohols } \\
\text { p-Tyrosol }\end{array}$ & Benzeneethanol, 4-hydroxy- & $501-94-0$ \\
\hline 20.25 & Vanillyl alcohol & $\begin{array}{l}\text { Benzenemethanol, 4-hydroxy-3- } \\
\text { methoxy- }\end{array}$ & $498-00-0$ \\
\hline 21.79 & Homovanillyl alcohol & $\begin{array}{l}\text { Benzeneethanol, 4-hydroxy-3- } \\
\text { methoxy- }\end{array}$ & $2380-78-1$ \\
\hline \multirow[t]{2}{*}{24.09} & Dihydroconiferyl alcohol & $\begin{array}{l}\text { Benzenepropanol, 4-hydroxy-3- } \\
\text { methoxy- }\end{array}$ & $2305-13-7$ \\
\hline & Cinnamic alcohols & & \\
\hline 15.10 & Cinnamyl alcohol & 2-Propen-1-ol, 3-phenyl & $4407-36-7$ \\
\hline 15.44 & Salicylic alcohol & Benzenemethanol, 2-hydroxy- & 90-01-7 \\
\hline 23.55 & p-Coumaric alcohol & Phenol, 4-(3-hydroxy-1-propenyl)- & $20649-40-5$ \\
\hline
\end{tabular}


Appendix 1. (Continued)

\begin{tabular}{llll}
\hline RT & COMMON NAME & SCIENTIFIC NAME & CAS \\
\hline \multirow{3}{*}{34.35} & Others & & $1740-19-8$ \\
& Dehydroabietic acid & $1-$ Phenanthrenecarboxylic acid, & $1,2,3,4,4 \mathrm{a}, 9,10,10 \mathrm{a}-$ octahydro-1,4a- \\
& & dimethyl-7-(1-methylethyl)- \\
& & $(1 \mathrm{R}, 4 \mathrm{aS}, 10 \mathrm{aR})-$ & \\
& & Non identified $(\mathrm{m} / \mathrm{z}=267)$ & \\
\hline
\end{tabular}

land abandonment and not in older stages (Tatoni, 1992). Germination (rate and germination delay) as well as growth, of this species are affected by allelochemicals of $P$. halepensis. These results show that $P$. halepensis could limit the establishment of other species by reducing interspecific competition (Reigosa et al., 2000), or by affecting the growth of species already present in the environment. These phenomena could as well facilitate the establishment of seedlings and growth of $P$. halepensis in its early stage (Reigosa et al., 1999).

The results showed variations in allelopathic effects due to age and organ of the donor plant as previously reported (Rice, 1984; Inderjit and Asakawa, 2001). Indeed, germination and growth of L. strictum were strongly affected by needle extracts of young pines and roots extracts of older pines. So, potential allelopathic effects of $P$. halepensis could be expressed mainly through natural leachates in the early stage following the establishment of this tree (Vyvyan, 2002) whereas, in later successional stages, they could be expressed mainly through root exudates, which significantly increase with tree age. Some authors believe that root exudation, a phenomenon still poorly investigated, could be very important directly or indirectly in allelopathic processes (Callaway \& Aschehoug, 2000).

$P$. halepensis affected germination and growth of the two target species in laboratory experiments. Even if Inderjit and Callaway (2003) and Bais et al. (2003) have shown that allelochemicals remain adsorbed in toxic concentrations in soil several authors have shown that their activity could be affected by various soil factors. For example Kobayashi (2004) and Keech et al. (2005) have shown that allelochemicals activy could be mediated by numerous soil factors (soil texture, organic and inorganic matter, moisture and organisms). Moreover, allelochemicals have the potential to be important regulators of carbon and nutrients cycling in coniferous forests (Kainulainen and Holopainen, 2002).

The different allelopathic effects between species could change interspecific competition and then mediate plant successional dynamic. Further field and laboratory experiments, on other wild species such as pre-forest and forest species (specially oaks), soils and under different light conditions, among others, are needed in order to demonstrate the complex interactions that occur in abandoned agricultural lands.

\section{Acknowledgments}

This study was financed by CNRS within the framework of the Zone Atelier "Arrière-pays Méditerranéen". We are grateful to the Natural Regional Park of the Luberon and also to the CEMAGreF of Aix-en-Provence, particularly Christian Ripert. The authors are indebted to many private owners who gave us permission to work in their forest. We would also like to thank Dr Nathalie Korboulewsky and Anders Mårell for proofreading the English, Dr Yves Letourneur (Oceanology Center UMR2196) for osmometer lending.

\section{References}

AFES (1995) Référentiel pédologique. Coll. Techniques et Pratiques. Paris : INRA Editions (Ed)

Anderson RC, Loucks OL (1966) Osmotic pressure influence in germination tests for antibiosis. Science 152: 771-773

Bais HP, Vepachedu R, Gilroy S, Callaway RM, Vivanco JM (2003) Allelopathy and exotic plants: from genes to invasion. Science 301: 1377-1380

Barbero M, Bonin G, Loisel R, Quézel P (1990) Changes and disturbances of forest ecosystems caused by human activities in the western part of the mediterranean basin. Vegetatio 87: 151-173

Bong-Seop K (1992) Effect of pine allelochemicals on selected species in Korea. Pp. 204-241 in: Rizvi V (ed) Allelopathy: Basic and Applied Aspects. London: Chapman \& Hall

Bousquet-Mélou A, Sophie L, Robles C, Greff S, Dupouyet S, Fernandez C (2005) Allelopathic potential of Medicago arborea, a Mediterranean invasive shrub. Chemoecology 15 (4): 193-198

Callaway RM \& Aschehoug ET (2000) Invasive plants versus their new and old neighbors: a mechanism for exotic invasion. Science 290: 521-523

Chiapusio G, Sanchez-Moreiras A, Reigosa MJ, Gonzalez L, Pellissier F (1997) Do germination indices adequately reflect allelochemical effects on the germination process? Journal of Chemical Ecology 23(11): 2445-2453

Chou CH, Fu CY, Li SY, Wang YF (1998) Allelopathic potential of Acacia confusa and related species in Taiwan. Journal of Chemical Ecology 24(12): 2131-2150

FAO (1998) World reference base for soil resources. Rome: International Society of Soil Science

Fiamegos YC, Nanos NG, Vervoort J, Stalikas CD (2004) Analytical procedure for the in-vial derivatization-extraction of phenolic and flavonoids in methanolic and aqueous plant extracts followed by gas chromatography with mass-selective detection. Journal of Chromatography A 1041: 11-18

Gilmore DW (1999) Historical Review and Current Models of Forest Succession and Interference. Pp. 237-251 in: Foy CL (ed) Principles and Practices in Plant Ecology. USA: CRC Press

Green JJ, Baddeley JA, Cortina J, Watson CA (2005) Root development in Mediterranean shrub Pistacia lentiscus as affected by nursery treatments. Journal of Arid Environment 61: 1-12

Hong NH, Xuan TD, Eiji T, Khanh TD (2004) Paddy weed control by higher plants from Southeast Asia. Crop Protection 23: $255-261$

Inderjit, Asakawa C (2001) Nature of interference potential of hairy vetch (Vicia villosa Roth) to radish (Raphanus sativus L.) does allelopathy play any role? Crop Protection 20: 261-265

Inderjit, Callaway RM (2003) Experimental designs for the study of allelopathy. Plant and Soil 256: 1-11 
Kainulainen P, Holopainen JK (2002) Concentrations of secondary compounds in Scots Pine needles at different stages of decomposition. Soil, Biology and Biochemistry 34: 37-42

Kobayashi K (2004) Factors affecting phytotoxic activity of allelochemicals in soil. Weed Biology and Management 4: 1-7

Kuiters AT (1990) Role of phenolic subtances from decomposition forest litter in plant-soil interactions. Acta Botanica Neerlandica 39: 329-348

Lambers H, Chapin III FS, Pons TL (1998) Plant Physiological Ecology. New York: Springer-Verlag

Lepart J, Debussche M, (1992) Human Impact on Landscape Patterning: Mediterranean Examples. Pp. 76-106 in: di Castri F (ed). Landscape Boundaries. New York: Springer-Verlag

Lepart J, Escarre J (1983) La succession végétale, mécanismes et modèles : analyse bibliographique. Bulletin d'Ecologie 14(3): 133-178

Loisel R (1976) La végétation de l'étage méditerranéen dans le Sud-Est continental français. PhD Université Aix-Marseille III, Marseille, France

Macchioni F, Cioni PL, Flamini G. Morelli I, Maccioni S, Ansaldi M (2003) Chemical composition of essential oils from needles, branches and cones of Pinus pinea, P. halepensis, $P$. pinaster and $P$. nigra from central Italy. Flavour and Fragrance Journal 18: 139-143

Maestre FT, Cortina J, Bautista S, Bellot J (2003) Does Pinus halepensis facilitate the establishment of shrubs in Mediterranean semi-arid afforestations? Forest Ecology Management 176: 147-160

Molina A, Reigosa MJ, Carballeira A (1991) Release of allelochemical agents from litter, throughfall, and topsoil in plantations of Eucalyptus globulus Labill in Spain. Journal of Chemical Ecology 17(1): 147-160

Nektarios PA, Economou G, Avgoulas C (2005) Allelopathic effects of Pinus halepensis needles on turfgrasses and biosensor plants. Hortscience 40(1): 246-250

Pasqua G, Monacelli B, Manfredini C, Loreto F, Perez G (2002) The role of isoprenoid accumulation and oxidation in sealing wounded needles of Mediterranean pines. Plant Science 163: 355-359

Pasqualini V, Robles C, Garzino S, Greff S, Bousquet-Mélou A, Bonin G (2003) Phenolic compounds content in Pinus halepensis Mill. needles: a bioindicator of air pollution. Chemosphere 52: 239-248

Pasternak T, Rudas V, Potters G, Jansen MAK (2005) Morphogenetic effects of abiotic stress: reorientation of growth in Arabidopsis thaliana seedlings. Environmental and Experimental Botany 53(3): 299-314

Pellissier F (1993) Allelopathic inhibition of spruce germination. Acta Oecologica 14(2): 211-218

Preiss E, Martin JL, Debussche M (1997) Rural depopulation and recent landscape changes in a Mediterranean region: consequences to the breeding avifauna. Landscape Ecology 12(1): 51-61

Quayyum HA, Mallik,AU, Orr DE, Lee PF (1999) Allelopathic potential of aquatic plants associated with wild rice: II. Isolation and identification of allelochemicals. Journal of Chemical Ecology 25(1): 221-228

Quézel P (2000) Taxonomy and Biogeography of Mediterranean Pines (Pinus halepensis and P. brutia). Pp. 1-12 in Trabaud L (ed) Ecology, Biogeography and Management of Pinus halepensis and $P$. brutia Forest Ecosystems in the Mediterranean Basin. Leiden: Backhuys

Quézel P, Médail F (2004) Ecologie et biogéographie des forêts du bassin Méditerranéen. Paris : Elsevier

Ray H, Hastings PJ (1992) Ariation within Flax (Linum usitatissimum) and Barley (Hordeum vulgare) in response to allelopathic chemicals. Theorical and Applied Genetics 84(3): 460-465

Reigosa MJ, Gonzalez L, Souto XC, Pastoriza JE (2000) Allelopathy in forest ecosystems. Pp 183-193 in Tauro P (Eds) Allelopathy in Ecological Agriculture and Forestry. Netherlands: Kluwer Academic

Reigosa MJ, Sanchez-Moreiras A, Gonzalez L (1999) Ecophysiological Approach in Allelopathy. Critical Reviews in Plant Sciences 18(5): 577-608

Reigosa MJ, Souto XC, Gonzalez L (1996) Allelopathic research: methodological, ecological and evolutionary aspects. Pp 213-231 in Tauro P (eds) Allelopathy: Field Observations and Methodology. Netherlands: Kluwer Academic

Rice EL (1984) Allelopathy. USA: Academic Press

Ripert C, Vennetier M (2002) Guide technique du forestier méditerranéen français. Chapître 2 bis : Evaluation des potentialités forestières. France: Cemagref (Ed.)

Rizvi SJH, Tahir M, Rizvi V, Kohli RK, Ansari A (1999) Allelopathic Interactions in Agroforestry Systems. Critical Reviews in Plant Sciences 18(6): 773-796

Roche P, Tatoni T (1995) Comparative study of secondary succession and resilience processes in Mediterranean-types ecosystems. Pp. 159-173 in: Bellan B, Bonin G, Emig C (eds) Functioning and dynamics of perturbated ecosystems. Paris: Lavoisier

Scherrer B (1984) Biostatistique. Chicoutimi: Gaëtan Morin.

Soil Survey Staff (1999) Soil Taxonomy, 2nd ed. USDA Natural Resources Conservation Service Agriculture Handbook

Tatoni T (1992) Evolution post-culturale des agrosystèmes de terrasses en Provence calcaire. Phytoécologie et impact humain. PhD Université de Provence - Aix-Marseille I, France

Vyvyan JR (2002) Allelochemicals as leads for new herbicides and agrochemicals. Tetrahedron 58: 1631-1649 